\title{
Institutional Reforms and Development of Corporate Governance and Banking System in China
}

\author{
Ratnam Vijayakumaran (Corresponding author)* \\ Department of Financial Management \\ Faculty of Management Studies and Commerce \\ University of Jaffna, Sri Lanka \\ Sunitha Vijayakumaran \\ Department of Management Studies \\ The Open University of Sri Lanka, Sri Lanka
}

Received: July 3, 2017 Accepted: Nov. 2, $2017 \quad$ Published: December 1, 2017

doi:10.5296/ajfa.v9i2.12382 URL: https://doi.org/10.5296/ajfa.v9i2.12382

\begin{abstract}
The aim of this paper is to review China's institutional reforms and consequent development of Chinese corporate governance system and financial system. As part of the wider economic reform initiated since the late 1970s, the Chinese government has adopted various measures aimed at reforming state owned enterprises (SOEs). These mainly include managerial autonomy, a management responsibility system, corporatization and partial privatization of former SOEs. In addition, the Chinese government took various steps to enhance the efficiency of the banking sector. The analysis shows that China's efforts to improve the corporate sector through its own unique gradual and piecemeal approach has been successful in terms of introducing a formal governance structure for the corporate sector, liberalizing its financial sector, improving governance of state owned banks, and most importantly, developing the private sector as the back bone of the economy.
\end{abstract}

Keywords: China, economic reform, corporate governance, ownership structure, banking system, private sector

JEL Classification: D02, D73, G18, G21, G30, G38, H11, O16, P27, P31 


\section{Introduction}

It is generally accepted that China's economic success is the result of its economic reform initiated in 1978, which is gradually transforming the central-command economic system into a market-based economy. In the initial stage of the transition, the government paid little attention to providing institutional infrastructures that were necessary for the capital market to function properly (Note 1). Although the transition necessitated the establishment of an almost entirely new set of institutions, China's political system inhibited the development of legal institutions and the evolution of local governmental authorities. Nevertheless, its desire to integrate globally has resulted in the gradual development of legal institutions, the decentralization of political institutions, the liberalization of the financial system, development of financial markets and the widespread growth of the private sector.

Unlike most former centrally planned economies, China has adopted a gradual and piecemeal approach instead of the overnight privatization of SOEs. As part of the wider economic reform, in the 1980s, the Chinese government adopted various measures aimed at reforming state owned enterprises (SOEs). These measures included increasing managers' decision making autonomy, introducing financial incentives, and bringing in performance contracts between the government and SOEs, which were mainly aimed at giving more latitude to SOE management in managing their firms and at aligning the goals of SOE management with those of the government (Naughton, 1995; Shirley and $\mathrm{Xu}, 2001$; Su 2005). These reforms measures were successful to a certain extent by reducing the role of governmental intervention in the management of SOEs and by improving their productivity (Groves, Hong, McMillan, and Naughton, 1994; Li, 1997). Nonetheless, the rights and responsibilities of SOE stakeholders and management were still ill-defined. Furthermore, as the reform efforts implemented thus far had not resulted in sufficient improvements in SOE performance, the government could not finance all SOEs itself (Aivazian, Ge, and Qiu, 2005; Jiang, Yue, and Zhao, 2009). Therefore, it sought to corporatize and partially privatize former SOEs while retaining its status as the controlling shareholder (Walter and Howie, 2003).

The latter two measures of SOE reforms mainly hinge on the Western-style modern corporate system, which is essentially characterized by the separation of ownership and control. This suggests that modern Chinese firms are inevitably subject to the issues of incentive incompatibility and information asymmetry, which often arise between managers and owners. Lin, Fang, and Li (1998) suggest that as a consequence of this, China's SOEs may face agency problems, such as moral hazard and managerial slacks and discretion. Therefore, giving appropriate incentives to the management becomes critical in firms in order to mitigate heightened agency problem and to motivate managers to pursue profit maximization objectives (Chow, 1997; Xu, Zhu, and Li, 2005).

Furthermore, the Chinese government traditionally wanted to retain some control in the companies, in part through partial retained ownership. This led to further conflicts between politicians/controlling shareholders and firms (Shleifer and Vishny, 1994; Young, Peng, Ahlstrom, Bruton, and Jiang, 2008). Furthermore, government ownership and control weaken the effectiveness of other governance mechanisms aimed at providing incentives for 
managers (Kato and Long, 2006a,b and 2011; Tian and Estrin, 2007). Despite these problems, the Chinese government has taken several steps to improve the corporate governance of firms as well as banks in recent years. In sections 2 and 3, we discuss the important institutional developments, namely corporate governance system and banking system, respectively, that are underpinning the growth of the corporate sector in China. Section 4 discusses present state of the private sector in China and Section 5 concludes.

\section{Corporate governance system in China}

In this section, we discuss the evolution of corporate governance of Chinese listed corporations, with particular emphasis on ownership structure and board structure.

\subsection{Evolution of corporations and financial markets}

The history of modern corporations in China is very short compared to other developing countries. Starting from 1984, stock companies have appeared in China, but formal trading did not start until the early 1990s. Beijing Tianquao Co, Ltd which was established in 1984 became the first joint stock corporation in China. In the same year, Shangai Feilo Acoustics Co., Ltd was the first Chinese corporation that publicly offered shares to the market (CSRC, 2006).

The establishment of the two stock markets in Shanghai in 1990 and in Shenzhen in 1991 with the objective of promoting the reform of SOEs was one of the most significant economic reforms in China. The government has thereby been successful in encouraging enterprises, especially SOEs to raise funds by issuing stocks and corporate bonds (Chi and Young, 2007). Moreover, the government has been seeking to improve the operating performance, and the corporate governance of SOEs through continuous economic and share-ownership reforms. Consequently, Chinese capital markets have seen a rapid development in terms of the number of listed companies, trading volume, and total market capitalization.

By early 2004, China's stock markets emerged as the eighth largest emerging market in the world with about 1300 listed firms and a market capitalization of over $\$ 550$ billion (Chen, 2005). As can been seen in Table 1, total number of listed companies has been increasing continuously every year since 2000 and at the end of 2010, a total of 2063 companies were listed on the two Chinese stock exchanges. The total market capitalization of these companies was 26.54 trillion RMB. The combined market capitalization of these two stock exchanges in 2010 accounted for about $66.69 \%$ of China's GDP (CSRC, 2010). At the end of 2013, a total of 2489 companies were listed on the two Chinese stock exchanges. Now China is the world's second largest stock market after the US in terms of combined market capitalization. Yet, the number of privately-owned listed companies was negligible until 1998, but boomed thereafter. The Chinese stock markets exhibit some prominent characteristics when compared to mature financial markets (Gordon and $\mathrm{Li}, 1999$ ). For example, the state or government plays a dual role as an owner of firms (dominance owners) and regulatory agency. While dividend income in China is subject to graduated tax rates based on the length of time the shares have been held, capital gains are generally taxed at the corporate income rate. 
Table 1. Important features of Chinese stock markets

\begin{tabular}{lcccccc}
\hline Year & $\begin{array}{c}\text { No. of } \\
\text { listed } \\
\text { companies }\end{array}$ & $\begin{array}{c}\text { No. of } \\
\text { foreign-invested } \\
\text { companies } \\
\text { (B-shares) }\end{array}$ & $\begin{array}{c}\text { No. of } \\
\text { overseas } \\
\text { listed } \\
\text { companies }\end{array}$ & $\begin{array}{c}\text { Total } \\
\text { outstanding } \\
\text { shares } \\
(100 \mathrm{mn} \\
\text { shares })\end{array}$ & $\begin{array}{c}\text { Total Market } \\
\text { capitalization } \\
(100 \text { million } \\
\text { Yuan })\end{array}$ & $\begin{array}{c}\text { Total } \\
\text { Turnover } \\
(100 \\
\text { million } \\
\text { Yuan })\end{array}$ \\
\hline 2000 & 1088 & 114 & 52 & 3792 & 48091 & 60827 \\
2001 & 1160 & 112 & 60 & 5218 & 43522 & 38305 \\
2002 & 1224 & 111 & 75 & 5875 & 38329 & 27990 \\
2003 & 1287 & 111 & 93 & 6428 & 42458 & 32115 \\
2004 & 1377 & 110 & 111 & 7149 & 37056 & 42334 \\
2005 & 1381 & 109 & 122 & 7630 & 32430 & 31663 \\
2006 & 1434 & 109 & 143 & 14926 & 89404 & 90487 \\
2007 & 1550 & 109 & 148 & 22417 & 327141 & 460556 \\
2008 & 1625 & 109 & 153 & 24523 & 121366 & 267113 \\
2009 & 1718 & 108 & 159 & 26163 & 243939 & 535987 \\
2010 & 2063 & 108 & 165 & 33184 & 265423 & 545634 \\
2011 & 2342 & 108 & 171 & 36096 & 214758 & 421650 \\
2012 & 2494 & 107 & 179 & 38395 & 230358 & 314667 \\
2013 & 2489 & 106 & 185 & 40569 & 239077 & 468729 \\
\hline & & & & & & \\
\hline
\end{tabular}

Sources: Annual reports of CSRC

Furthermore, China's securities market is open to foreign investors. While International investors were for the first time allowed to invest in China's B share market in 1992, after ten years, foreign institutions have been allowed to invest directly into China's A share market via the Qualified Foreign Institutional Investor (QFII) scheme (Note 2). As can been seen in Table 2, with the opening of Chinese economy for foreign investors, there has been a steady growth in number of QFIIs (from 27 to 106) and approved investment quotas in USD billion (from 24 USD billion to 19.72 USD billion). We can also observe that the total assets held by the QFIIs have steadily increased from 2004 to 2010 except in 2008. Furthermore, among QFIIs commercial banks accounted for about 29\% in 2007 and $20 \%$ in 2010 (Note 3).

Furthermore, since 2001, eligible foreign companies can offer and list shares in China's markets. A further significant development was that since 2002 foreign companies are also allowed to take over Chinese listed companies. International investors' participation has helped to promote Chinese capital markets. At the same time, it has brought into the capital market long-term funds, which are helpful for the growth of Chinese corporations, as well as advanced investment philosophies and good expertise (CSRC, 2006). 
Table 2. Qualified foreign institutional investors (QFII) in China 2004-2010

\begin{tabular}{cccccc}
\hline Year & $\begin{array}{c}\text { QFII licensed } \\
\text { foreign } \\
\text { institutions }\end{array}$ & $\begin{array}{c}\text { Approved } \\
\text { investment } \\
\text { quotas in USD } \\
\text { billion }\end{array}$ & $\begin{array}{c}\text { Total QFII } \\
\text { assets }\end{array}$ & $\begin{array}{c}\text { Securities held } \\
\text { by QFII }\end{array}$ & $\begin{array}{c}\text { Percentage of } \\
\text { securities to } \\
\text { total assets }\end{array}$ \\
\hline 2004 & 27 & 3.7 & 24 & 16.2 & $66.6 \%$ \\
2005 & 34 & 5.6 & 39 & 34.7 & $90 \%$ \\
2006 & 44 & 7.3 & 196 & 137 & $70 \%$ \\
2007 & 52 & 9.995 & 258.8 & 175.5 & $61.4 \%$ \\
2008 & 76 & 13.405 & 178.78 & 104.78 & $58.6 \%$ \\
2009 & 94 & 16.67 & 289.9 & 237 & $81.8 \%$ \\
2010 & 106 & 19.72 & 297.1 & 265.8 & $89.5 \%$ \\
\hline
\end{tabular}

Source: CSRC annual reports 2004-2010

\subsection{The company Law and the Chinese Securities Regulations Commission}

The institutional framework for corporate governance in China mainly draws from both the 1994 Company Law of the People's Republic of China and the Chinese Securities Regulations Commission (CSRC). The 1994 Company Law improved property rights by establishing the firm as a legal entity that owns assets. Furthermore, the company law facilitated the restructuring of traditional large and medium sized SOEs as legal entities, and the establishment of a modern corporate system by standardizing the organization and the behavior of the companies. It defines the functions and responsibilities of shareholders, board of directors, and board of supervisors. In 2006, a fundamental review of Chinese company law was enacted, creating two types of limited companies: the limited liability companies (LLC private companies) and the joint stock company (JSC public companies). This brought the legal context much in line with the company law of other countries. The Enterprise Bankruptcy Law was introduced only in November 1988 for an initial trial period. In April 1991, the Civil Procedural Law, which established the bankruptcy procedure for companies, was enacted. Yet, due to that fact that most of the firms were owned by the government or government agents which have social and political objectives such as maintaining employment, the number of bankruptcies was very low compared to international standards (Cao, 1998). A new corporate bankruptcy law was enacted in 2007, which applied to SOEs, foreign investment enterprises, and domestic companies. Yet, Tomasic and Zhang (2012) note that China's bankruptcy judges are extremely cautious in the implementation of the new law's reorganization provisions due to the political considerations.

The establishment of the two stock exchanges was an important milestone toward the development and implementation of the rule of law and in securing property rights for private enterprises. Yet, in the early 1990s, local leaders retained a significant influence over the listing process and the enforcement of secondary market regulation, but in the late 1990s, the China Security Regulatory Commission (CSRC) was able to consolidate its influence. The stock market regained the confidence of public investors and has enjoyed rapid expansion since then. CSRC is responsible for monitoring stock exchange activities and its main 
objective is to protect investors. From time to time, the CSRC, along with other authorities, has issued supplemental regulations, administrative rules, guidelines and codes (e.g. the Provisional Regulations on Public Offering and Trading, and the Measures on the Administration of Futures Exchanges). In 2001, the China Security Regulatory Commission (CSRC) formulated some basic norms of corporate governance, aiming at protecting minority shareholders from controlling shareholders' expropriation. The guideline also discourages the combination of the positions of chairperson of the board of directors and general manager (CEO duality). In 2002, a Code of corporate governance for listed companies was formulated for the first time by the CSRC. This prescribed basic principles for the protection of investors' rights, as well as basic rules and standards for directors, supervisors, and senior management. The code was intended to be the major measuring standard for the evaluation of listed companies' corporate governance structure.

\subsection{Ownership structure}

Until 2005, Chinese corporations could issue non-tradable and tradable shares. Thus, the equity structure of most listed companies was segmented, being characterized by the co-existing of exchange-tradable shares held mainly by public investors, and largely stated-owned non- tradable shares, which could only be transferred through negotiation among designated parties. This structure stemmed mainly from a lack of consensus among policy-makers on the corporate shareholding structure in the early years, a lack of clarity over the role and functions of the securities market, and a lack of awareness of how to manage state assets through capital markets. Chinese corporations typically issue non-tradable shares to SOEs, and other state owned legal persons and tradable shares to public investors.

Chinese listed firms have traditionally issued four types of tradable shares; each with its own unique characteristics. China's mainland companies issue A-share and B-share in Shanghai and Shenzhen. A-shares are denominated in local currency (RMB) mainly for the domestic investors. B-shares which are traded in U.S. dollars are mainly for overseas investors. Mainland companies issue $\mathrm{H}$-share in Hong Kong, and $\mathrm{N}$-shares (American Depository Receipts - ADRs) in the US. Before the 2005 reform, only one third of total shares issued by the companies were tradable. The rest were non-tradable, which significantly affected the liquidity of the China's stock markets.

\subsubsection{The 2005 split share structure reform}

In 2005, the CSRC launched trial reforms of non-tradable shares (referred to hereafter as the reform), with the objective of releasing the market from the historical hangover that afflicted it, and better protecting the investors. Following the positive results of the trial, a full-scale reform campaign was soon carried out among listed companies. Specifically, the non-tradable shares were floated through the open markets. The reform aimed to gradually eliminate the difference between the two types of shares and to balance the interest between the two categories of shareholders in a market-oriented way. In order to make government-owned shares legally tradable, state shareholders were required to compensate tradable shareholders through a share conversion process. This was achieved through fair negotiations between holders of non-tradable shares and tradable shares. The compensation was decided at 
shareholders' meetings, without any government intervention. The reform effectively diluted the government-owned share portion, attenuating government-related agency costs.

As of December 31, 2007, 1,298 listed companies, which represented 98\% of the total listed companies subject to the reforms, had either initiated or completed the process of non-tradable share reform. Additionally, all new IPOs taking place since mid-2006 no longer have non-tradable shares. The non-tradable share reform successfully resolved problems such as the dual-pricing of shares of the same listed company. It restored the pricing functions of the capital market, greatly improved market efficiency and paved the way for further improvements in the corporate governance and development of the capital market.

Table 3 reports the evolution of the ownership structure, board structure of Chinese listed firms over the period 2003-2010. We observe a persistent decrease in state ownership and legal person ownership throughout the sample period. In particular, state ownership which accounted on average for one third of total shares decreased from $35.9 \%$ in 2003 to $8.3 \%$ in 2010. We can observe similar trend for legal person ownership which decreased from $21.9 \%$ in 2003 to $0.086 \%$ in 2010 . In contrast, shares owned by top management increased from $0.4 \%$ in 2003 to $0.8 \%$ in 2010 .

Table 3. Evolution of the ownership structure and board structure

\begin{tabular}{lrrrrrrrr}
\hline Year & 2003 & 2004 & 2005 & 2006 & 2007 & 2008 & 2009 & 2010 \\
\hline State ownership & 0.359 & 0.344 & 0.333 & 0.284 & 0.248 & 0.210 & 0.114 & 0.083 \\
Legal person ownership & 0.219 & 0.224 & 0.215 & 0.186 & 0.156 & 0.129 & 0.094 & 0.086 \\
Managerial ownership & 0.004 & 0.011 & 0.013 & 0.019 & 0.030 & 0.036 & 0.048 & 0.080 \\
Foreign ownership & 0.044 & 0.041 & 0.042 & 0.042 & 0.043 & 0.038 & 0.029 & 0.035 \\
Board size & 9.814 & 9.658 & 9.580 & 9.405 & 9.343 & 9.203 & 9.089 & 9.027 \\
Proportion of independent directors & 0.327 & 0.342 & 0.347 & 0.351 & 0.356 & 0.357 & 0.359 & 0.360 \\
\hline
\end{tabular}

Source: The China Stock Market Accounting Database (CSMAR)

Another important outcome related to the 2005 reform is that listed companies have been allowed to incentivize their managers with shares and stock options. In January 2006, the CSRC issued "The Administrative Rules of Equity Compensation of Listed Companies", which allow the companies that have successfully completed their split-share-reforms to adopt equity based compensation plans for their managers. According to these measures, equity incentives include restricted stocks and stock option plans. This also provided a strong incentive for the top managers of listed companies to complete the reform at the earliest possible in order to participate in the new incentive scheme. It is expected that in addition to increasing the income standards of the management, granting them stocks or equity options helps align their interest with those of the shareholders and with the long-term development of the enterprise (Note 4).

Yet, state ownership and control in former SOEs hinders the use of modern governance mechanisms such as managerial ownership (Conyon and He, 2011; Kato and Long, 2011; R.Vijayakumaran, 2014; Dixon, Guariglia and Vijayakumaran, 2015; S.Vijayakumaran, 2016). However, after three decades of reform, managerial ownership has emerged as one of 
the important governance mechanisms at least in non-state/private Chinese listed firms (Conyon and He, 2011; Walder, 2011; R.Vijayakumaran, 2014; Dixon, Guariglia and Vijayakumaran, 2015; S.Vijayakumaran, 2016). For example, Dixon et al. (2015) show that share ownership by managers in private Chinese firms increases their incentive to involve in risk taking activities such as international expansion. Similarly, R. Vijayakumaran (2014) provides evidence that managerial ownership works as an effective governance mechanism only for private firms to mitigate asymmetric information problem and thus mitigate financial constraints faced by them and, similarly, to provide managers with incentive to align their interests with those of shareholders and reduce agency costs in their firms. In a similar vein, S. Vijayakumaran (2016) finds that managerial ownership provides managers with incentive to use more debt capital in the capital structure of their firms.

\subsection{Board of directors}

In accordance with company law, Chinese firms operate under a two-tier board structure, with a board of directors (management board) and a board of supervisors (with employees and others like the German model). The board of directors is responsible for the strategic operations of the firm.

One of the important legal rights of shareholders is the right to elect the board of directors, which have certain rights and duties in regard to the incumbent management. In the United States, the boards of directors, which rely heavily on directors from outside a firm, have enormous power in appropriating and dismissing top executives and in determining their compensation. In Japan, creditor financial institutions, which are often large shareholders as well, often dispatch directors to monitor managerial decision makings. China's commercial law also identifies the board of directors as the top level decision-making body of a company. Directors are appointed at general shareholders' meetings. In practice, however, the authority and prestige of China's boards were comparatively low relative to those in other countries. This is because the majority of listed firms were controlled by the state and thus almost $90 \%$ of the board members of these firms were government officials who lacked the necessary knowledge or experience (Su, 2005).

In 2002, the CSRC issued Guidelines for introducing independent directors in the boards of listed companies. In particular, each listed company was required to have at least two independent directors, and by June 2003 at least one-third of the board had to be made up by independent directors (including at least one professional in accounting). Independent directors could be nominated by the board of directors, the board of supervisors, or any shareholder holding 5 percent of the shares. According to the Guidelines, the independent directors were expected to play a better monitoring role than non-executive directors, being more "independent". They were not allowed to "hold posts in the company other than the position of director" and were asked to "maintain no relations with the listed company and its major shareholders that might prevent them from making objective judgment independently." Independent directors were required to provide independent opinions on substantial decisions, such as the nomination, appointment or removal of directors, the appointment or removal of senior managers, the compensation of directors and senior managers, substantial 
connected transactions (with a value higher than RMB3 million or 5\% of latest audited net asset value), and other issues deemed substantial.

As can be seen in Table 3, we observe a slight decrease in the number of board of directors listed firms over the period 2003-2010 with the number of board of directors declined from 9.814 in 2003 to 9.027 in 2010. By contrast, we observe a steady increase in the proportion of independent directors of companies which increased from $0.327 \%$ in 2003 to $0.36 \%$ in 2010 . Yet, in practice, many independent directors in China are, however, appointed by controlling shareholders and their independence from the management is not certain (Clarke, 2003; Su, 2005).

\subsection{Board of supervisors}

The main functions of the supervisors are to oversee finances, ensure diligent actions of the directors and senior management, and report any impropriety, abuse of discretionary power, or action that affects the firm. The Company Law does not specify the proportion of representatives of shareholders or employees on the board of supervisors, except that at least a third should be worker representatives. Moreover, whilst the supervisory board in the German model sits between the shareholders and the management board and can appoint board of directors, in the Chinese model, the supervisory board does not have the power to hire and fire directors. Consequently, the supervisory power of Chinese supervisory boards is relatively soft and seeks to act through influence. Commentators point out that Chinese supervisory boards are often ineffective, and have little influence on firms' activities, since their members have low education and professional experience and their meetings are not well attended (Dahya, Karbhari, Xiao, Yang, 2003; Tong, 2003; Tricker, 2009).

\subsection{Comparisons of the Chinese corporate governance system with that of developed countries}

There is divergence of corporate governance systems around the world. In the developed world, one of the most prominent distinctions has been made between the Anglo-American market based corporate governance model (also known as principal-agent model or shareholder model) which characterizes the US and UK, and the network based models (stakeholder), which operates in Germany and Japan (Ahmadjian and Robbins, 2005). The main features of the former are diffuse ownership, a separation of ownership and control, and external market-based financing and discipline, while the latter features concentrated ownership, insider control, and coordinated networks of firms and financial institutions. More specifically, the government is not very involved in the corporate governance system in the US. By contrast, banks and workers play a crucial role in Germany's governance system. They provide a substantial amount of loans to corporations, own their shares, and intervene in their corporate governance through the appointment of directors or the general monitoring of their performance.

Additionally, in China, state ownership uniquely provides another corporate governance model with its traditional ideology of employees being masters of the enterprises. In particular, many listed companies in China are still heavily influenced by the government, 
which controls them directly through share ownership, or indirectly by allocating capital to them at favorable rates through state-owned banks. Thus, to some extent, the Chinese government supplements the market-based economy.

\section{China's banking system and bond market}

Unlike in developed countries, in China alternative governance mechanisms, such as reputation and personal relationship (also known as Quanxi (Note 5) in China) play crucial role in the financing of firms, especially in the development of entrepreneurial firms. As Allen, Qian, and Qian (2005) discuss, out of three sectors in China, namely, State Sector (SOEs), Listed Sector and Unlisted private Sector, the former two sectors use the formal financing channels, such as bank financing and equity and bond markets for financing investment, while a large number of private firms with arguably poor applicable legal and financial sectors use the Quanxi system to finance the investment activities which contribute to the most of the growth of China's economy. Yet, recent studies suggest that following the liberalization of China's financial system and the improvement in the corporate governance of the banking sector, Chinese banks play an important role in monitoring corporate activities and improving the efficiency of corporations. In this study, since our focus is on the listed firms it is important to have an insight about the Chinese banking system, and recent reforms so as to clearly understand their implications for the firms' corporate governance and financing of investment.

Before 1978, China's financial system was a mono-bank system with only one bank-the People's Bank of China (PBOC), which played both the role of central bank and commercial bank. Beginning in the late 1970s, there was a structural but gradual change in the banking sector. In 1978, in line with economic reforms, the PBOC was split into four state-owned banks(known as the Big Four),with a multi-layered system that separates central banking functions and commercial lending. These were: the PBOC which has become China's central bank; the Bank of China (BOC) which specialized in transactions related to foreign trade and investment; the People's Construction Bank of China (PCBC) which specialized in transactions related to fixed investment; and the Agriculture Bank of China (ABC) which specialized in all banking business in rural area. Additionally, in 1984, the Industrial and Commercial Bank of China (ICBC) was established to take over all commercial transactions (deposit-taking and lending business) of the PBOC. ICB quickly became China's largest bank accounting for half of all bank lending and it is still the leading bank in China (Cull and $\mathrm{Xu}$, 2003).

Since 1984, the Chinese banking system has been undergoing a series of further reforms, with the objective of making the Big Four as real enterprises. Since 1985, these banks have been permitted to engage in business outside of their designated economic sector.

Furthermore, in 1994, three wholly state-owned policy banks were established to take over the policy lending functions from the four state owned banks (Note 6). From that point onwards, the Big Four were known as commercial banks and were expected to operate in accordance with market principles. The state-owned commercial banks have also been subject to reform in terms of managerial and mechanistic aspects. For example, the 
importance of risk management has been reinforced and their managers are held responsible for their lending decisions. Other subsequent developments made during the 1990s, include the transformation of urban credit cooperatives into commercial banks, permitting non-state commercial banks, and introducing standard accounting and prudential norms. Furthermore, because of the large volume of policy loans and weak internal controls, by the late 1990s, the accumulated large non-performing loans (NPLs) of the Big Four state owned commercial banks and their insolvency had become important issue for the government. In 1998, the government therefore injected RMB 27 billion of capital into the four state-owned banks and transferred the NPLs to four newly established asset management companies.

To enhance the efficiency of the banking sector by increasing competition among banks, in 1986, the Chinese government began to establish new banks, known as joint-equity banks and city banks (Note 7). By the end of 2004, five of the 11 domestic joint-equity banks were publicly listed on China's stock exchanges. However, because the largest shareholders in most of joint-equity banks are usually SOEs, they are indirectly controlled by the government (Note 8).

Until 2004, the Big Four were SOEs solely owned by the Chinese government. Yet, in 2005, the government started to privatize these banks through the recruitment of strategic investors (by providing minority foreign ownership stakes) and by listing them on the stock exchange. The China Banking Regulatory Commission (CBRC) and the Central Huijin Investment Company were set up in 2002 in order to provide closer scrutiny and better monitoring of banking activities, and to facilitate restructuring, reform, and initial public offerings of state-owned banks, respectively

Another important aspect of the Chinese banking system is the entry of foreign banks which predominantly takes place through setting up branches directly. Prior to 1993, foreign banks were only allowed to establish branches in certain cities to conduct foreign-currency business with foreign firms and citizens. From 1993 onwards, however, the government started lifting restrictions on foreign bank lending and allowed foreign banks in China to conduct both foreign- and local-currency business with foreign firms and citizens, and to conduct foreign-currency business with domestic firms. There were 190 foreign bank branches in China in 2001 (Lin, 2011).

Following its accession to the World Trade Organization (WTO) in December 2001, China has further opened up its banking sector to foreign banks in full scale in the following five-year period. Foreign banks in 13 cities were allowed to conduct local-currency business with domestic firms from 2003 onwards. Large foreign banks were allowed to acquire significant stake and become strategic partners of major state-owned banks (Note 9). By 2006, there were over 300 foreign bank branches in China.

Despite many policy and regulatory changes have been initiated from early part of the 1980, empirical researches carried out in the first half of the 2000s such as by Bandt and Li (2003) and Cull and $\mathrm{Xu}$ (2003) show that the Chinese banking system discriminates against private firms and private enterprises are generally significantly less likely to obtain loans and receive smaller loans and are subject to higher loan standards. Bandt and Li (2003) further argue that 
the Chinese government's majority ownership of banks inevitably lead to less efficient resource allocation and specially capital allocation is biased in favor of SOEs. Since bank managers benefit only marginally from higher bank profitability, they prefer to lend to state-related firms because they enjoy the perks of their relationships with local government officials, who, for example, can use their political power to help arrange a job for a bank manager's relative, or facilitate their entry into the Chinese Communist Party.

Yet, more recent research argues that participation of foreign capital and management in state banks, listing of state banks and many other city commercial banks on stock exchanges from mid-2000, has exerted external market pressure on banks to follow commercial judgment and prudence in their lending practices (Jia, 2009 and Lin, 2011) (Note 10). Qin (2007) argues that China's accession to WTO has made its foreign trade and investment regime much more liberalized and less opaque than a decade ago, specially by institutionalizing the process of China's domestic reform externally through the force of WTO obligations. Consistent with these developments, Firth et al. (2009) provide evidence that Chinese banks provide loans to financially healthier and better-governed firms. Ayyagari, Demirguc-Kunt, and Maksimovic (2008) suggest that unlike financing from alternative channels, financing from China's formal financial system (e.g., bank financing) is associated with faster firm growth. Generally, recent studies based on China's financial system conclude that Chinese banks exercise commercial judgment and prudence in their lending and are becoming more efficient in allocating credit to private firms. Thus, Chinese banks' traditional lending bias in favor of state-owned enterprises is less likely to prevail.

In China, the corporate bonds market lags behind the development of the equity market. Although bonds were first issued in 1986, the corporate bond market has only begun to expand after 2000, when new rules governing issuance were implemented. Local firms, besides the giant SOEs, are also encouraged to issue corporate bonds and market forces increasingly determine the spread on bonds. Yet, China's bond market is still very small compared to its huge banking scoter.

\section{Growth of the Chinese private sector}

One of the most significant changes in China's economy brought about by the market-oriented reforms is the emergence of a significant private sector. Consequently, the country has gradually shifted away from the complete reliance on state-owned and collective enterprises, towards a mixed economy. Private enterprises now play a major role in promoting exports, growth, innovation, and employment in China. The development of the private sector was considered as an important element of the unique Chinese "dual-track" approach to economic reform. In addition to officially recognizing private enterprises in 1988 , in the 1990s, government policies began to encourage the transformation of SOEs and collectives firms into private enterprises (Hasan, Wachtel, and Zhou, 2009). The Government has also granted approval for banks to lend to private businesses, thus promoting the growth of numerous small- and medium-sized firms. Further, the Chinese private sector was formally accepted as an integral part of the economy in 1999 by an amendment to the constitution. As in the Western countries, the private sector is considered as the major engine of China's rapid 
growth (Allen et al., 2005). In 2004, the National Congress approved a constitutional amendment to protect private property rights, granting "private property" an equal legal status to "public property". Firth et al. (2009), based on data from the National Bureau of Statistics, note that the private sector accounted for roughly 50\% of GNP in 2005, and was expected to rise to at least $75 \%$ by 2010 .

As for the listed companies, during the last decade there have been significant changes in ownership structure. In particular, Walder (2011) reports that the private control of listed corporations in China increased from $6.5 \%$ in 1999 to $35 \%$ in 2007. Similarly, Vijayakumaran (2014) observes that the proportion of private controlled listed firms has increased from $26.76 \%$ in 2005 to around $40 \%$ in 2010. By contrast, the proportion of state-controlled firms has declined from $70.32 \%$ to $56.73 \%$ over the same time period. As discussed in Conyon and $\mathrm{He}$ (2012), this trend can be explained by the growing number of firms coming to the exchange as private controlled firms, and by the 2005 split share reform, which converted previously non tradable state and legal person shares to tradable shares. This clearly shows that with the deepening of China's market reforms, private controlled firms are becoming more and more common in China. These changes suggest that reforms are making rapid progress and are in line with what would be expected in a market-based economy.

\section{Conclusion}

The above analysis shows that China's efforts to improve the corporate sector through its own unique gradual and piecemeal approach has been successful in terms of introducing a formal governance structure for the corporate sector, liberalizing its financial sector, improving governance of state owned banks, and most importantly, developing the private sector as the back bone of the economy. Furthermore, there have been significant improvements in the political and legal environment. As discussed in Hasan et al. (2009), the Chinese political system is becoming increasingly structured with regularized decision-making subject to the rule of law while the legal environment has also improved, with the laws being enacted nationally and locally to protect property rights. Despite the widespread adoption of western corporate governance practices and the development of the private sector in China, the effectiveness of their corporate governance practices has yet to be fully evaluated.

\section{References}

Ahmadjian, C. L., \& Robbins, G. E. (2005). A clash of capitalisms: Foreign shareholders and corporate restructuring in 1990s Japan. American Sociological Review, 70(3), 451-471. https://doi.org/10.1177/000312240507000305

Aivazian,V.A, Ge,Y., \& Qiu, J. (2005). Can corporatization improve the performance of state-owned enterprises even without privatization? Journal of Corporate Finance, 11, 791-808. https://doi.org/10.1016/j.jcorpfin.2004.11.001

Allen, F., Qian, J., and Qian, M. (2005).Law, finance, and economic growth in China. Journal of Financial Economics, 77, 57-16. http://dx.doi.org/10.1016/j.jfineco.2004.06.010 
Ayyagari, M., Demirguc-Kunt, A., \& Maksimovic, V. (2008). How well do institutional theories explain firms' perceptions of property rights? Review of Financial Studies, 21, 1833-1871. https://doi.org/10.1093/rfs/hhl032

Berle, A. A., \& Means, G.C. (1932). The Modern corporation and private property, New York: Macmillan Publishing Co.

Brainard, L., \& Fenby, J. (2007).Chinese takeout. Wall Street Journal, 20 Feb., A17.

Brandt, L., \& Li, H. (2003). Bank discrimination in transition economies: ideology, information, or incentives? Journal of Comparative Economics, 31(3), 387-413. https://doi.org/10.1016/S0147-5967(03)00080-5

Cao, S. (1998). Bankruptcy Law in China.Harvard China Review, 1, 36-39.

Chen, J.J. (2005). Corporatization of China's state-owned enterprises and corporate governance. Challenges for China's development: An enterprise perspective, 4, 58.

Chen, S, Sun, S.Y.J., \& Donghui, Wu. (2010). Client importance, institutional improvements, and audit quality in China: An office and individual auditor level analysis. The Accounting Review, 85, 127-158. https://doi.org/10.2308/accr.2010.85.1.127

Chi, J., \& Young, M. (2007). Corporate governance and regulation in China: Openness and challenges, 21, 361-365. https://doi.org/10.1016/j.ribaf.2006.12.003

Chow, G. (1997). Challenges of China's economic system for economic theory. American Economic Review, 87(2), 321-327. http://www.jstor.org/stable/2950939

Clarke, D. (2003). Corporate governance in China: An overview. China Economic Review, 14, 494-507. https://doi.org/10.1016/j.chieco.2003.09.019

Conyon, M., \& He, L. (2011). Executive compensation and corporate governance in China. Journal of Corporate Finance, 17, 1158-1175. https://doi.org/10.1016/j.jcorpfin.2011.04.006

Conyon, M., \& He, L. (2012). CEO compensation and corporate governance in China, Corporate governance: An International Review, 20(6), 575-592. https://doi.org/10.1111/j.1467-8683.2012.00935.x

CSRC. (2006). Annual Report, People's Republic of China: China Securities Regulatory Commission.

CSRC. (2010). Annual Report, People's Republic of China: China Securities Regulatory Commission.

Cull, R., \& Xu, L.C. (2003). Who gets credit? The behavior of bureaucrats and state banks in allocating credit to Chinese state-owned enterprises. Journal of Development Economics, 71, 533-559. https://doi.org/10.1016/S0304-3878(03)00039-7

Cull, R., \& Xu, L.C. (2005). Institutions, ownership, and finance. The determinants of profit reinvestment among Chinese firms. Journal of Financial Economics, 77, 117-146. https://doi.org/10.1016/j.jfineco.2004.05.010 
Dixon, R., Guariglia, A., \& Vijayakumaran, R. (2015). Managerial ownership, corporate governance and firms' exporting decisions: Evidence from Chinese listed companies. The European Journal of Finance, 1-39. https://doi/abs/10.1080/1351847X.2015.1025990

Dahya, J., Karbhari, Y., Xiao, J., \& Yang, M. (2003).The usefulness of the supervisory board report in China. Corporate Governance: An International Review, 11(4), 308- 321. https://doi.org/10.1111/1467-8683.00329

Firth, M., Lin, C., Liu, P., \& Wong, S. M. (2009). Inside the black box: Bank credit allocation in China's private sector. Journal of Banking \& Finance, 33(6), 1144-1155. https://doi.org/10.1016/j.jbankfin.2008.12.008

Groves, T., Hong, Y., McMillan, J., \& Naughton, B. (1994). Autonomy and incentives in Chinese state enterprises. Quarterly Journal of Economics, 109, 181-209. https://doi.org/10.2307/2118432

Hasan, I., Wachtel, P., \& Zhou, M. (2009). Institutional development, financial deepening and economic growth: Evidence from China. Journal of Banking and Finance, 33, 157-170.

Jia, C. X., (2009). The effect of ownership on the prudential behavior of banks - the case of China. Journal of Banking \& Finance, 33, pp. 77-87. https://doi.org/10.1016/j.jbankfin.2007.03.017

Jiang, G., Yue, H., and Zhao, L. (2009).A re-examination of China's share issue privatization. Journal of Banking and Finance, 33, 2322-2332. https://doi.org/10.1016/j.jbankfin.2009.06.008

Kato, T., \& Long, C. (2006a). CEO turnover, firm performance, and enterprise reform in China: Evidence from micro data. Journal of Comparative Economics, 34, 796-817. https://doi.org/10.1016/j.jce.2006.08.002

Kato, T., \& Long, C. (2006b). Executive turnover and firm performance in China. American Economic Review, 96, 363-367. https://doi.org/10.1257/000282806777212576

Kato, T., \& Long, C. (2011). Tournaments and managerial incentives in China's listed firms: New evidence. China Economic Review, 22(1), 1-10. https://doi.org/10.1016/j.chieco.2010.08.001

Li, W. (1997). The impact of economic reform on the performance of Chinese state enterprises, 1980-1989. Journal of Political Economy, 105, 1080-1106. https://doi.org/10.1086/262106

Lin, H. (2011). Foreign bank entry and firms' access to bank credit: evidence from China. Journal of Banking \& Finance, 35, 1000-1010. https://doi.org/10.1016/j.jbankfin.2010.09.015

Lin, J, Y., Fang, C., \& Li, Z. (1998). Competition, policy burdens, and state-owned enterprise reform. American Economic Review, 88(2), 422-27. http://www.jstor.org/stable/116960

Qin, J, Y. (2007). Trade, Investment and beyond: The Impact of WTO Accession on China's Legal System. The China Quarterly, 191, 720-741. https://doi.org/10.1017/S0305741007001695 


\section{Macrothink}

Asian Journal of Finance \& Accounting

ISSN 1946-052X

2017, Vol. 9, No. 2

Naughton, B. (1995). Growing Out of the Plan: Chinese Economic Reform, 1978-1993. New York: Cambridge University Press. https://doi.org/10.1017/CBO9780511664335

North, D. C. (1990). A transaction cost theory of politics. Journal of theoretical politics, 2(4), 355-367. https://doi.org/10.1177/0951692890002004001

North, D. C. (1994). Institutions matter. Economic History, 9411004.

Shirley, M., \& Xu, L. C. (2001).The empirical effects of performance contracts. Journal of Law, Economics, and Organization, 17(1), 168-200. https://doi.org/10.1093/jleo/17.1.168

Shleifer, A., \& Vishny, R. (1994).Politicians and firms. Quarterly Journal of Economics, 109, 995-1025. https://doi.org/10.2307/2118354

$\mathrm{Su}$, D. (2005). Corporate finance and state enterprise reform in China. China Economic Review, 16, 118-148. https://doi.org/10.1016/j.chieco.2004.09.003

Tian, L., \& Estrin, S. (2007). Debt financing, soft budget constraints, and government ownership: evidence from China. Economics of Transition, 15(3), 461-481. https://doi.org/10.1111/j.1468-0351.2007.00292.x

Tomasic, R., \& Zhang, Z. (2012).China's enterprise bankruptcy law. Law and Policy for China's Market Socialism, 80, 55.

Tong, D. (2003). The state of corporate governance in China. Paper presented at the American Accounting Association Conference, Hawaii.

Tricker, R. (2009). Corporate governance: Principles, policies, and practices, University press, Oxford.

Young, M. N., Peng, M.W., Ahlstrom, D., Bruton, G. D., \& Jiang, Y. (2008). Corporate governance in emerging economies: A review of the principal-principal perspective. Journal of Management Studies, 45(1), 196-220. https://doi.org/10.1111/j.1467-6486.2007.00752.x

Vijayakumaran, R. (2014). Corporate governance and corporate finance: evidence from Chinese listed companies. (Unpublished doctoral dissertation) Durham University, Durham. http://etheses.dur.ac.uk/10965/

Vijayakumaran, S. (2016). Leverage and debt maturity of Chinese listed firms: determinants and effects on corporate performance. (Unpublished doctoral dissertation) Durham University, Durham. http://etheses.dur.ac.uk/11897/

Walder, A. (2011). From control to ownership: China's managerial revolution. Management and Organization Review, 7(1), 19-38. http://dx.doi.org/10.1111/j.1740-8784.2009.00171.x

Walter, C., \& Howie, F. (2003). Privatizing China. John Wiley \& Sons (Asia) Pte Ltd., Singapore.

Xu L., Zhu, T., \& Li, Y-M. (2005). Politician control, agency problems and ownership reform: Evidence from China. Economics of Transition, 13(1), 1-24. 


\section{Notes}

Note 1. Hereby, we denote with institutions those formal constraints such as rules, laws, and regulations, as well as informal constrains such as norms of behavior, conventions, self-imposed codes of conduct, and enforcement mechanisms, which structure human interaction to reduce uncertainty and provide incentives (North, 1990, 1994). Without institutions, markets neither develop nor function properly.

Note 2. This was a program that permitted, on a selective basis, certain licensed global institutional investors to participate in China's mainland stock exchanges by buying and selling yuan-denominated "A" shares. Foreign access to these shares is limited by specified quotas that determine the amount of money that the licensed foreign investors are permitted to invest in China's capital markets.

Note 3. Other main QFIIs include investment management firms, brokers (securities companies) and investment banks, insurance companies..

Note 4. Although these changes were gradual and evolutionary compared with those experienced in other transition countries, Walder $(2011$, p. 23) refers to this as a Chinese version of "managerial revolution". It should be noted, however, that the rise in managerial ownership has been slower in China compared to market economies (Walder, 2011; 2011; Conyon and He, 2012).

Note 5. Guanxi (literally means relationship or connection) "(in China) the system of social networks and influential relationships which facilitate business and other dealings" (online oxford dictionary).

Note 6. These are the State Development Bank, the Agricultural Development Bank of China, and the Export and Import Bank of China.

Note 7. The first joint-equity bank was the Bank of Communication.

Note 8 . The China Minsheng Bank was the only joint-equity private bank wholly owned by private shareholders in China.

Note 9. For example, the Hongkong and Shanghai Banking Corporation (HSBC) acquired a $19.9 \%$ stake of the Bank of Communication. The Bank of America and the Royal Bank of Scotland have become strategic partners of the China Construction Bank and the Bank of China, respectively

Note 10. We can observe similar development in the behaviour of auditors in China, for example, Chen et al. (2010) who investigate the relation between client importance and audit quality, suggest that auditors in China are more likely to compromise audit quality for economically important clients when the institutions for investor protection are weak. However, with the institutional improvements in China, auditors become more concerned about litigation risks and regulatory sanctions instead of their economic incentives.

*This paper was written while Dr. R. Vijayakumaran was a UK Commonwealth doctoral scholar at Durham University Business School, UK and Dr. S. Vijayakumaran was a doctoral scholar at Durham University Business School. 